\title{
Feeding ecology of the common shrimp Crangon crangon in Port Erin Bay, Isle of Man, Irish Sea
}

\author{
Chul-Woong Oh, Richard G. Hartnoll*, Richard D. M. Nash \\ Port Erin Marine Laboratory, School of Biological Sciences, University of Liverpool, Port Erin, Isle of Man IM9 6JA, \\ British Isles
}

\begin{abstract}
The diet of the common shrimp Crangon crangon (L.) was studied in Port Erin Bay (Isle of Man, Irish Sea) by analysis of stomach contents, with comparison by season and size class of diet composition and prey diversity. Monthly samples were taken from April 1995 to March 1998. Mysids and amphipods together constituted the dominant prey, accounting for $>60 \%$ of the diet in both percent occurrence and percent abundance. Mysids were most important irrespective of season or size class. The small size group $(<10 \mathrm{~mm} \mathrm{CL})$ tended to be more dependent on epifaunal and infaunal organisms, reflecting ontogenic changes in diet. Trophic diversity and equality of diet varied with season and size class, with highest values in spring. Diet composition differed among seasons and size classes. Niche overlap index was higher between size classes (Schoener index: maximum $=0.83$ in summer, minimum $=0.67$ in autumn) than between seasons (Schoener index: maximum $=0.70$ between summer and autumn, minimum $=0.46$ between spring and winter). Shrimp size was significantly correlated with size of certain prey (e.g. Schistomysis spiritus and Gammarus sp.) though not with size of infaunal prey (e.g. Iphinoë trispinosa and Corbula sp.). This is discussed in relation to predator visibility, food availability and energy investment in handling prey. Feeding behaviour was linked to moult stage, ovarian condition and season. During premoult and postmoult there was low foregut fullness. Females carrying eggs and with advanced ovaries also displayed low fullness, suggesting that feeding activity is affected by the reproductive cycle. Fish otoliths in the stomachs showed that larger females (mainly $>10 \mathrm{~mm} \mathrm{CL}$ ) prey on 0-group fish co-occurring in the study area - plaice (Pleuronectes platessa), dab (Limanda limanda) and sandeel (Ammodytes tobiannus). This suggests that predation by adult C. crangon can affect mortality of young fish in Port Erin Bay.
\end{abstract}

KEY WORDS: Crangon crangon $\cdot$ Prey items $\cdot$ Feeding behaviour $\cdot$ Port Erin Bay

\section{INTRODUCTION}

The common shrimp Crangon crangon (L.) is an abundant species around the North and Irish Seas and the English Channel in shallow waters with a sand or mud substrate (Tiews 1970, Redant 1984). A wide range of biological and ecological aspects of C. crangon has been studied because of the shrimp's high commercial value. Studies of its feeding habits indicate that it is an ecologically important benthic predator (Evans 1983, 1984, Pihl \& Rosenberg 1984, Evans \&

*Corresponding author. E-mail: rgh@liv.ac.uk
Tallmark 1985, Reise 1978, 1985, Boddeke et al. 1986, Beukema 1992), leading to a number of studies on the impact of this species upon the structure and function of the in- and epifauna (Kuipers \& Dapper 1981, Evans \& Tallmark 1985, Jensen \& Jensen 1985, Pihl 1985, Hedqvist-Johnson \& Andre 1991, Jonsson et al. 1993, Nilsson et al. 1993, Bonsdorff \& Pearson 1997, van der Veer et al. 1998). C. crangon is generally a carnivorous nocturnal predator that buries in the sediment during the day (Lloyd \& Yonge 1947, Pihl \& Rosenberg 1984). Feeding behaviour is similar to that of other crangonid shrimps such as Crangon septemspinosa (Price 1962), C. franciscorum and C. nigricauda (Wahle 1985), C. 
affinis (Kosaka 1970, Hong \& Oh 1989) and C. allmani (Allen 1960, 1966).

The main investigations into the diet of Crangon crangon have been on the Swedish west coast (Pihl \& Rosenberg 1984) and in the North Sea (Allen 1966, Boddeke et al. 1986). Pihl \& Rosenberg (1984) noted that diet composition was highly variable, both spatially and seasonally. The important constituents of the diet were infauna on the sandy silt bottom of the Swedish west coast (Pihl \& Rosenberg 1984), but pelagic calanoid copepods on the sand bottom of the Dutch west coast (Boddeke et al. 1986). Therefore the diet of $C$. crangon is determined by the composition of the benthic community and the abundance of available prey, both of which are strongly correlated with substrate type (Ansell et al. 1999). So different sediment types lead to different feeding strategies within this species. C. crangon have also been implicated as a major predator of young plaice Pleuronectes platessa (van der Veer \& Bergman 1987).

Experiments in captivity have shown that feeding activity is affected by physiological condition, such as moulting and reproduction (e.g. Lloyd \& Yonge 1947). Other shrimps-Macrobrachium rosenbergii (De Haan) (Harpaz et al. 1987) and Penaeus esculentus (Wassenberg \& Hill 1984) - show similar responses in captivity. To date, however, there is no information available on the diet of Crangon crangon in the Irish Sea.

The study area (Port Erin Bay, Isle of Man, Irish Sea) is a small embayment dominated by 2 predators, Crangon crangon (Oh et al. 1999) and the plaice (Pleuronectes platessa) (Nash et al. 1992, 1994). In the present paper we examine: (1) the natural diet of $C$. crangon in Port Erin Bay, (2) seasonal changes of diet in different size groups, (3) prey size selection, and (4) the effects of some life history factors on feeding activity. We also discuss the interaction between $C$. crangon and co-occurring young fish.

\section{MATERIALS AND METHODS}

Sampling. Samples of Crangon crangon were obtained during routine weekly or monthly (depending on the weather) sampling between April 1995 and March 1998 in Port Erin Bay, Isle of Man $\left(54^{\circ} 05^{\prime} \mathrm{N}\right.$, $\left.4^{\circ} 54^{\prime} \mathrm{W}\right)$, Irish Sea. The bay has a sand and gravel substrate (Pirrie et al. 1932, Bruce et al. 1963). All individuals were collected between 0 and $6 \mathrm{~m}$ below chart datum. A $1.5 \mathrm{~m}$ beam trawl with a fine mesh inner codend $(3 \times 3 \mathrm{~mm})$ was used between April and June, and a $2 \mathrm{~m}$ beam trawl with a cod-end liner $(6 \times 6 \mathrm{~mm})$ during the rest of the year. Five transects were sampled, orthogonal to the shore, covering an area of $1850 \mathrm{~m}^{2}$.
Specimens of C. crangon were fixed in $4 \%$ neutralised formalin and, after $24 \mathrm{~h}$, stored in $70 \%$ alcohol. Stomach contents of C. crangon were identified in 2595 individuals ranging in carapace length from 7.6 to $17.5 \mathrm{~mm}$ (see Oh et al. 1999).

Laboratory analysis. The following data were recorded for each shrimp: carapace length $(\mathrm{CL}$, the shortest distance between the posterior margin of orbit and the mid-dorsal posterior edge of the carapace); sex, based on examination of the endopod of the first pleopods and the presence of the appendix masculina or egg-carrying setae; and gonad maturation stage following the criteria of Meredith (1952). Moult condition was distinguished as 3 stages - postmoult (Stage A \& B), intermoult (Stage C) and premoult (Stage D) based on the setogenic development of the uropods, following Smith \& Dall (1985).

To evaluate the effects of season, sex, moulting stage and reproductive condition on stomach fullness, the relative degree of stomach fullness was assessed visually and each foregut was assigned to 1 of 5 categories derived from the points method described by Wear \& Haddon (1987): a category representing 95 to $100 \%$ of foregut contents was given 100 points; $<95$ and $>65 \%$, 75 points; $<65$ and $>35 \%, 50$ points; $<35$ and $>5 \%$, 25 points; and $5 \%$ or less, 2.5 points.

Prey items in the stomachs were determined to the lowest taxonomic level possible. Specimens with $<2.5$ points were excluded from analyses, and sand was excluded as a prey category. Prey were determined as both present or absent, and as a proportion of the number of points assigned for the stomach fullness (i.e. abundance). Diet was determined for 4 seasons: spring (March to May), summer (June to August), autumn (September to November) and winter (December to February). Two size classes - small $(<10 \mathrm{~mm} \mathrm{CL})$ and large (>10 mm CL) - were discriminated. To investigate the relationship between predator size and prey size, the body sizes of 4 prey items were measured: carapace length for mysids (Schistomysis spiritus) and cumaceans (Iphinoë trispinosa), cephalon length for amphipods (Gammarus sp.) and shell width for bivalves (Corbula sp.).

Data analysis. Numerous indices have been used for describing the importance of different prey in the diet of fish (Hynes 1950, Hyslop 1980). The percent frequency of occurrence $(F)$ and relative abundance $(A)$ for each type of prey were estimated by the following formulae:

$$
\begin{aligned}
& \% F=\left(n_{i} / N\right) \times 100 \\
& \% A=\left(S_{i} / S_{t}\right) \times 100
\end{aligned}
$$

where $n_{i}$ is the number of shrimps with prey $i$ in their stomach, $N$ the total number of shrimps with stomach 
contents, $S_{i}$ the number of prey $i$ and $S_{\mathrm{t}}$ the total number of prey items.

Trophic diversity $\left(H^{\prime}\right)$ in diet was calculated by season and size class according to the Shannon-Wiener index (Cody \& Diamond 1975). Diet equality was also calculated for the different size classes and seasons, using Pielou's evenness index (Pielou 1975).

The degree of food niche overlap was calculated using Schoener's (1970) index $\left(R_{\mathrm{o}}\right)$. Values of $R_{\mathrm{o}}$ range from 0 (no overlap) to 1 (complete overlap). When there is dietary overlap, index values $\leq 0.8$ are considered to be indicative of major differences (Cartes \& Sardà 1989). This index was used to establish dietary affinities between different seasons and size classes.

Statistical analysis. Three-dimensional (log-linear) contingency tables were used to test seasonal variation in the diet of different size classes (Zar 1984). When the 3 factors were mutually associated, further partial association tests between factors were carried out.

Two-way contingency table analyses were employed to test for independence between prey types and season or size groups. This statistical technique is simple and can readily identify the source of variation when diets are expressed numerically or according to presence/absence (Crow 1982, Cortés 1997). To avoid too many cells having expected frequencies $<5$ (Sokal \& Rohlf 1995), some prey categories were pooled into a larger category. This statistical procedure was also applied to association testing between stomach fullness and factors related to life history (sex, moult stage and gonad maturity) and feeding activity.

\section{RESULTS}

\section{Size composition}

Seasonal size distributions of the Crangon crangon analysed for diet are given in Fig. 1. A total of 2595 individuals were used for this study. A KolmogorovSmirnov 2-sample test showed that there were no significant differences in size distribution among seasons (Table 1).

Table 1. Crangon crangon. Kolmogorov-Smirnov 2-sample test for frequency distribution of size between pairwise seasons. In parentheses $d_{\max }$ (maximum differences) values

\begin{tabular}{|llcc|}
\hline & \multicolumn{1}{c}{ Spring } & Summer & Autumn \\
\hline Spring & & & \\
Summer & $\mathrm{p}>0.06(0.545)$ & & \\
Autumn & $\mathrm{p}>0.06(0.545)$ & $\mathrm{p}>0.1(0.455)$ & \\
Winter & $\mathrm{p}>0.10(0.455)$ & $\mathrm{p}>0.7(0.273)$ & $\mathrm{p}>0.4(0.364)$ \\
\hline
\end{tabular}
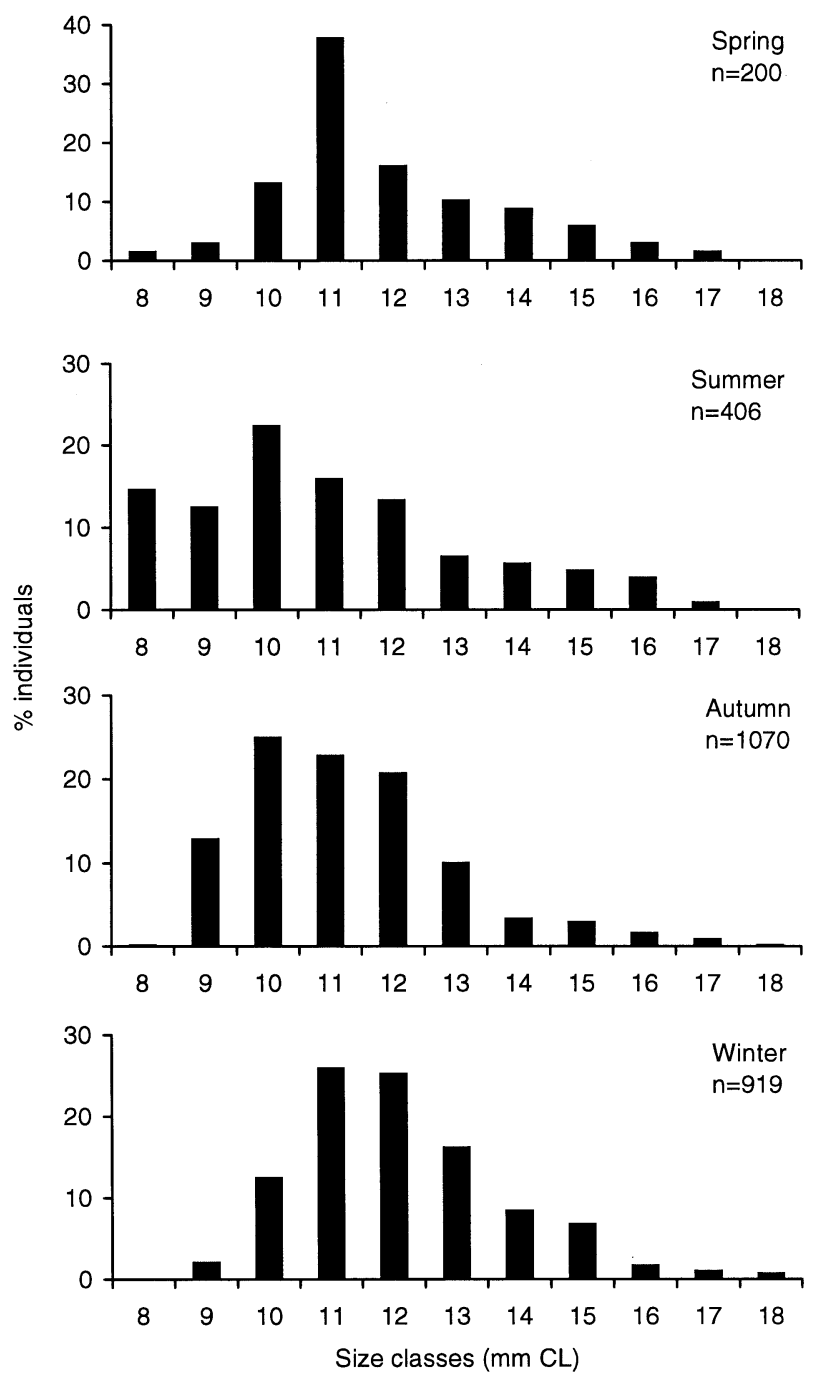

Fig. 1. Crangon crangon. Seasonal size structure of individuals examined for stomach content analysis

\section{Diet composition}

Of the 2595 stomachs examined, 1231 (51.9\%) registered $>2.5$ points on the stomach fullness scale. Mysids (mainly Schistomysis spiritus) and amphipods (mainly Gammarus sp.) were the most important food items overall, both being present in $>25 \%$ of the foreguts examined and comprising $>25 \%$ of total prey abundance (Table 2, Fig. 2). The other prey categories contributed only small proportions to the diet.

\section{Difference of diet by season and size class}

Mysids and amphipods were the predominate prey items in spring (Fig. 3), when these 2 items combined accounted for $>40 \%$ of the diet according to both 
abundance and occurrence. Both indices highlighted their increasing importance through the year, dominating the diet in summer (ca 50\%) and autumn (ca $60 \%$ ). In winter mysids alone dominanted the prey $(>50 \%)$. Other items, such as isopods, molluscs, cumaceans (Iphinoë trispinosa) and other crustaceans (copepods, cypris larvae, crab postlarvae), declined in relative importance from spring through winter. The grand total $\chi^{2}$ - and $G$-values indicate a significant difference $(\mathrm{df}=30, \mathrm{p}<0.001)$ in the seasonal proportions

Table 2. Crangon crangon. Diet composition in the 4 seasonal groups and 2 size groups $(\% F$, frequency of occurrence; $\% N$, percentage abundance)

\begin{tabular}{|c|c|c|c|c|c|c|c|c|c|c|c|c|c|c|c|c|}
\hline \multirow{4}{*}{$\begin{array}{l}\text { Season } \\
\text { Size class } \\
\text { No. examined } \\
\text { Prey items }\end{array}$} & \multicolumn{4}{|c|}{ Spring } & \multicolumn{4}{|c|}{ Summer } & \multicolumn{4}{|c|}{ Autumn } & \multicolumn{4}{|c|}{ Winter } \\
\hline & & \multicolumn{2}{|c|}{ Large } & \multicolumn{2}{|c|}{ Small } & \multicolumn{2}{|c|}{ Large } & \multicolumn{2}{|c|}{ Small } & \multicolumn{2}{|c|}{ Larger } & \multicolumn{2}{|c|}{ Small } & \multicolumn{2}{|c|}{ Larger } \\
\hline & & & & 4 & \multicolumn{2}{|c|}{165} & \multicolumn{2}{|c|}{81} & \multicolumn{2}{|c|}{334} & & 68 & & 22 & & 75 \\
\hline & $\% F$ & $\% N$ & $\% F$ & $\% N$ & $\% F$ & $\% N$ & $\% F$ & $\% N$ & $\% F$ & $\% N$ & $\% F$ & $\% N$ & $\% F$ & $\% N$ & $\% F$ & $\% N$ \\
\hline POLYCHAETA & - & - & 10.6 & 4.1 & 3.6 & 3.7 & 4.9 & 2.1 & 0.9 & 0.6 & 2.2 & 1.2 & 0.8 & 0.4 & 12.0 & 6.4 \\
\hline CRUSTACEA & & & & & & & & & & & & & & & & \\
\hline Mysidacea & & & & & & & & & & & & & & & & \\
\hline Schistomysis spiritus & 37.4 & 12.1 & 40.4 & 17.4 & 29.1 & 19.9 & 25.9 & 19.8 & 35.9 & 27.9 & 57.5 & 54.8 & 63.1 & 49.1 & 61.1 & 57.2 \\
\hline Praunus flexuosus & 5.0 & 1.1 & 11.7 & 5.8 & 8.5 & 5.0 & 11.1 & 6.8 & 6.3 & 3.7 & 3.7 & 2.7 & 6.6 & 3.8 & 0.6 & 0.4 \\
\hline Praunus sp. & 2.8 & 0.5 & 3.2 & 2.5 & 1.8 & 1.3 & 4.9 & 1.7 & 2.1 & 1.1 & 1.5 & 0.6 & 1.6 & 1.1 & - & - \\
\hline Unidentified & 5.0 & 3.2 & 3.2 & 1.7 & - & - & 4.9 & 2.1 & 5.1 & 4.1 & 4.1 & 3.2 & 8.2 & 5.3 & 14.9 & 11.1 \\
\hline Amphipoda & & & & & & & & & & & & & & & & \\
\hline Gammarus sp. & 42.1 & 13.7 & 14.9 & 7.4 & 30.3 & 36.9 & 28.4 & 35.4 & 25.2 & 26.9 & 11.2 & 14.8 & 10.7 & 7.9 & 5.1 & 4.0 \\
\hline Corophium sp. & 5.0 & 1.6 & 3.2 & 1.7 & 9.1 & 7.6 & 4.9 & 2.5 & 4.2 & 4.7 & 1.5 & 1.4 & 2.5 & 1.9 & 2.3 & 1.3 \\
\hline Unidentified & 25.2 & 10.5 & 25.5 & 11.6 & 3.6 & 2.6 & 1.2 & 0.8 & 5.1 & 4.4 & 1.5 & 0.9 & 0.8 & 0.4 & 0.6 & 0.4 \\
\hline Isopoda & & & & & & & & & & & & & & & & \\
\hline Idotea neglecta & 2.8 & 5.8 & 3.2 & 9.9 & 3.6 & 2.4 & 4.9 & 3.4 & 2.4 & 1.3 & 3.7 & 2.1 & - & - & 1.7 & 1.1 \\
\hline Idotea emarginata & 2.8 & 0.5 & - & - & - & - & 1.2 & 0.4 & - & - & 0.4 & 0.2 & 1.6 & 0.8 & 0.6 & 0.2 \\
\hline Idotea sp. & - & - & 7.4 & 2.5 & - & - & 1.2 & 0.4 & - & - & 0.7 & 0.8 & - & - & - & - \\
\hline Unidentified & 2.8 & 1.1 & 11.7 & 3.3 & - & - & - & - & 0.6 & 0.4 & 0.4 & 0.5 & - & - & 1.1 & 0.9 \\
\hline Cumacea & & & & & & & & & & & & & & & & \\
\hline Iphinoë trispinosa & 21.5 & 12.1 & - & - & 6.7 & 5.5 & - & - & 7.8 & 8.8 & 0.7 & 0.6 & 2.5 & 1.9 & - & - \\
\hline Decapoda & & & & & & & & & & & & & & & & \\
\hline Crangon crangon & - & - & 7.4 & 3.3 & 1.2 & 0.5 & 6.2 & 3.4 & 0.3 & 0.2 & 1.9 & 1.1 & - & - & 0.6 & 0.2 \\
\hline Philocheras trispinosus & - & - & 7.4 & 1.7 & 0.6 & 0.3 & 1.2 & 0.8 & - & - & 2.2 & 0.8 & 1.6 & 0.8 & 3.4 & 2.8 \\
\hline Hippolyte varians & 2.8 & 0.5 & - & - & - & - & - & - & - & - & - & - & - & - & 1.1 & 0.4 \\
\hline Other crustaceans & & & & & & & & & & & & & & & & \\
\hline Copepoda & 10.3 & 5.3 & 3.2 & 1.7 & 9.1 & 5.5 & 1.2 & 0.4 & 1.8 & 2.2 & - & - & 1.6 & 1.1 & 0.6 & 0.2 \\
\hline Crab postlarvae & - & - & 7.4 & 2.5 & - & - & 4.9 & 2.1 & 1.2 & 0.7 & 0.4 & 0.3 & - & - & - & - \\
\hline Cypris larva & 5.0 & 6.3 & 3.2 & 2.5 & 1.8 & 1.0 & - & - & 2.1 & 1.5 & 0.7 & 0.3 & - & - & - & - \\
\hline Digested crustaceans & 10.3 & 5.3 & 11.7 & 4.1 & 0.6 & 0.3 & 2.5 & 1.3 & 1.5 & 1.2 & 1.5 & 1.7 & 1.6 & 2.3 & 2.3 & 1.7 \\
\hline MOLLUSCA & & & & & & & & & & & & & & & & \\
\hline Bivalvia & & & & & & & & & & & & & & & & \\
\hline Corbula sp. & 7.5 & 3.2 & 4.3 & 1.7 & 1.2 & 0.5 & 2.5 & 0.8 & 1.8 & 0.9 & 2.2 & 1.8 & 0.8 & 3.0 & 6.9 & 3.4 \\
\hline Dosinia sp. & 5.0 & 2.1 & 3.2 & 0.8 & 1.2 & 1.0 & - & - & 1.2 & 0.7 & - & - & 0.8 & 0.8 & - & - \\
\hline Musculus discors & - & - & 3.2 & 0.8 & 1.2 & 0.8 & 1.2 & 0.4 & 0.3 & 0.1 & 0.4 & 0.2 & 0.8 & 0.4 & - & - \\
\hline Gastropoda & & & & & & & & & & & & & & & & \\
\hline Cima sp. & 2.8 & 1.1 & - & - & - & - & - & - & - & - & 0.4 & 0.2 & 4.1 & 7.5 & 1.7 & 0.6 \\
\hline Lunatia sp. & 2.8 & 0.5 & - & - & - & - & - & - & 1.5 & 1.1 & - & - & 4.9 & 3.8 & 1.1 & 0.4 \\
\hline Abra sp. & 12.2 & 4.2 & 11.7 & 4.1 & 0.6 & 0.5 & - & - & 3.0 & 2.4 & 3.4 & 1.8 & 2.5 & 1.9 & 2.9 & 1.9 \\
\hline NUDIBRANCHIA & - & - & - & - & 0.6 & 0.5 & - & - & 0.3 & 0.1 & 1.9 & 0.8 & 0.8 & 0.4 & 0.6 & 0.2 \\
\hline FORAMINFERA & - & - & 3.2 & 1.7 & 0.6 & 0.5 & 4.9 & 3.0 & 0.9 & 0.6 & 0.4 & 0.3 & - & - & - & - \\
\hline NEMATODA & 15.0 & 6.3 & - & - & - & - & - & - & 0.3 & 0.3 & 0.4 & 0.3 & 0.8 & 1.1 & 0.6 & 0.2 \\
\hline PISCES & & & & & & & & & & & & & & & & \\
\hline Fishes & - & - & 18.1 & 4.1 & 2.4 & 1.0 & 19.8 & 7.2 & 1.8 & 0.7 & 8.2 & 3.5 & 2.5 & 1.1 & 9.1 & 3.4 \\
\hline Fish eggs & - & - & - & - & 0.6 & 0.3 & 2.5 & 1.7 & - & - & - & - & - & - & - & - \\
\hline ALGAE & 7.5 & 3.2 & 7.4 & 3.3 & 3.0 & 2.4 & 7.4 & 3.4 & 2.7 & 3.1 & 3.7 & 3.0 & 4.1 & 3.4 & 1.7 & 1.1 \\
\hline INSECTA & - & - & - & - & 0.6 & 0.5 & - & - & 0.3 & 0.1 & 0.4 & 0.3 & - & - & 0.6 & 0.4 \\
\hline Unidentified remains & 7.5 & 2.1 & 14.9 & 5.0 & 0.6 & 1.0 & 1.2 & 0.8 & 0.6 & 0.5 & 1.1 & 0.8 & 1.6 & 1.5 & 1.1 & 0.6 \\
\hline
\end{tabular}


Table 3. Crangon crangon. Contingency table analysis of the seasonal variation of 11 different categories of food items found in the stomachs. Values are total number of prey observed in each season, with expected values given in parentheses. $\chi^{2}-$ and $G$-statistics are highly significant $\left({ }^{* * *} \mathrm{p}<0.001\right)$

\begin{tabular}{|c|c|c|c|c|c|c|c|}
\hline Prey type & Spring & Summer & Autumn & Winter & $N_{i}$ & $\chi^{2}$ & $G_{i}$ \\
\hline Polychaeta & $5(7)$ & 19 (13) & $14(34)$ & 31 (15) & 69 & 31.14 & 30.55 \\
\hline Mysidacea & 65 (143) & $172(278)$ & 766 (733) & $480(330)$ & 1483 & 152.51 & 161.10 \\
\hline Amphipoda & $74(83)$ & $272(162)$ & 466 (428) & 54 (192) & 866 & 178.47 & 205.72 \\
\hline Isopoda & $33(10)$ & $19(20)$ & $40(51)$ & $12(23)$ & 104 & 60.81 & 42.06 \\
\hline Cumacea & $23(13)$ & $21(26)$ & $90(69)$ & $5(31)$ & 139 & 36.20 & 46.30 \\
\hline Decapoda & $7(5)$ & $13(10)$ & $14(25)$ & $18(12)$ & 52 & 10.83 & 11.17 \\
\hline Other crustaceans & $45(16)$ & $35(32)$ & $71(83)$ & $18(38)$ & 169 & 63.31 & 49.13 \\
\hline Mollusca & $30(20)$ & $14(39)$ & $84(102)$ & $78(46)$ & 206 & 46.70 & 47.30 \\
\hline Pisces & $5(8)$ & $26(15)$ & $30(40)$ & $19(18)$ & 80 & 11.45 & 10.32 \\
\hline Algae & $10(9)$ & $17(17)$ & $50(45)$ & $14(20)$ & 91 & 2.65 & 2.86 \\
\hline Miscellaneous & $24(8)$ & 17 (15) & $26(40)$ & $13(18)$ & 80 & 40.79 & 28.98 \\
\hline$N_{i}$ & 321 & 625 & 1551 & 742 & 3339 & & \\
\hline$\chi^{2}$ & 196.15 & 144.01 & 43.65 & 251.06 & & $634.86^{* * *}$ & \\
\hline$G_{i}$ & 155.73 & 140.81 & 48.79 & 290.16 & & & $635.49^{* * *}$ \\
\hline
\end{tabular}

of prey types consumed (Table 3). Among prey types, the main source of variation comes from amphipods $\left(\chi^{2}=178.47\right)$ and mysids $\left(\chi^{2}=152.51\right)$, as demonstrated by the seasonal changes of prey items. Among seasons, the main source of variation is winter $\left(\chi^{2}=251.06\right)$. The important food items (i.e. amphipods and mysids), along with the minor food items, contribute to the seasonal difference in diet. The post hoc contingency table analysis revealed that eliminating the major

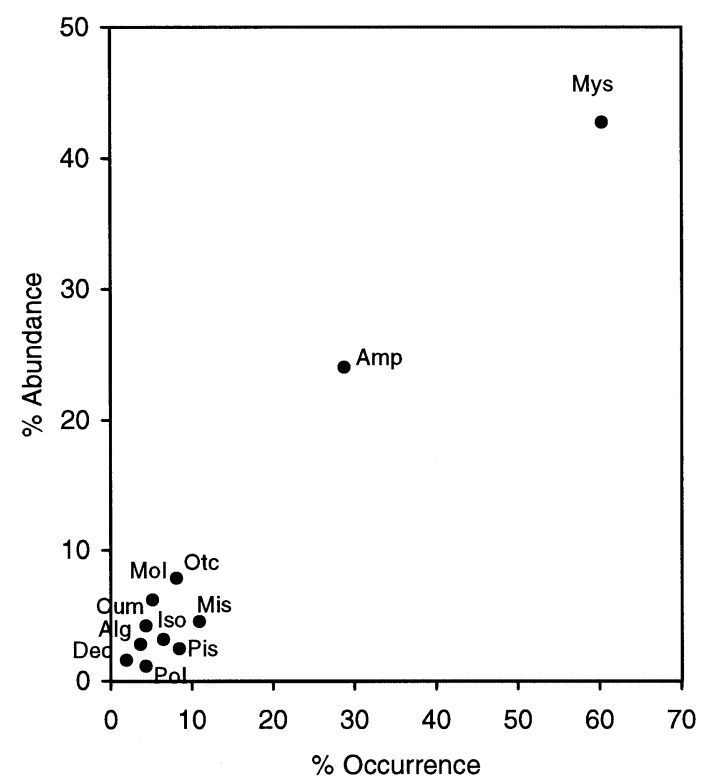

Fig. 2. Crangon crangon. Relative importance of major stomach contents in overall diets for all combined samples irrespective of season and size class (Alg, algae; Amp, amphipods; Cum, cumaceans; Dec, decapods; Iso, isopods; Mis, miscellaneous; Mol, molluscs; Mys, mysids; Pis, fish; Pol, polychaetes; Otc, other crustaceans) source of variability from rows and columns did not suffice to yield a nonsignificant $\chi^{2}$ (Table 4 ).

Diet composition in the 2 size classes-small ( $<10 \mathrm{~mm} \mathrm{CL})$ and large ( $>10 \mathrm{~mm} \mathrm{CL})$ - is shown in Fig. 4. For small shrimps, mysids and amphipods combined comprised $>60 \%$ of prey, in both abundance and occurrence. For large shrimps, mysids were clearly dominant. The proportion of other food categories was marginally higher in small compared to large shrimps. In small shrimps, the benthic components, molluscs (bivalves and gastropods) and cumaceans (Iphinoë trispinosa), ranked as third and fourth most important prey items respectively. In large shrimps, decapods and fish ranked as the third most important prey items by percent abundance and percent occurrence, respectively. There was a significant difference $(\mathrm{df}=$ $10, \mathrm{p}<0.001$ ) (see Table 5) in the proportions of prey types consumed by the 2 size classes. Among prey types, the main sources of variation were Cumacea and Amphipoda. The posthoc contingency table analy-

Table 4. Crangon crangon. Results of post hoc contingency table analysis (log-likelihood) of the seasonal variation of 11 different categories of food items found in the stomachs after elimination of selected rows and/or columns

\begin{tabular}{|lcr|}
\hline $\begin{array}{l}\text { Row(s) or column(s) } \\
\text { eliminated }\end{array}$ & $\begin{array}{c}\text { Significance } \\
\text { of } \chi^{2}\end{array}$ & $\begin{array}{c}\text { Sample } \\
\text { size }\end{array}$ \\
\hline Amphipoda & $<0.001$ & 2473 \\
Amphipoda, Mysidacea & $<0.001$ & 990 \\
Amphipoda, Mysidacea, & $<0.001$ & 717 \\
other crustaceans & $<0.001$ & 2597 \\
Winter & $<0.001$ & 1785 \\
Winter, Amphipoda & & \\
\hline
\end{tabular}



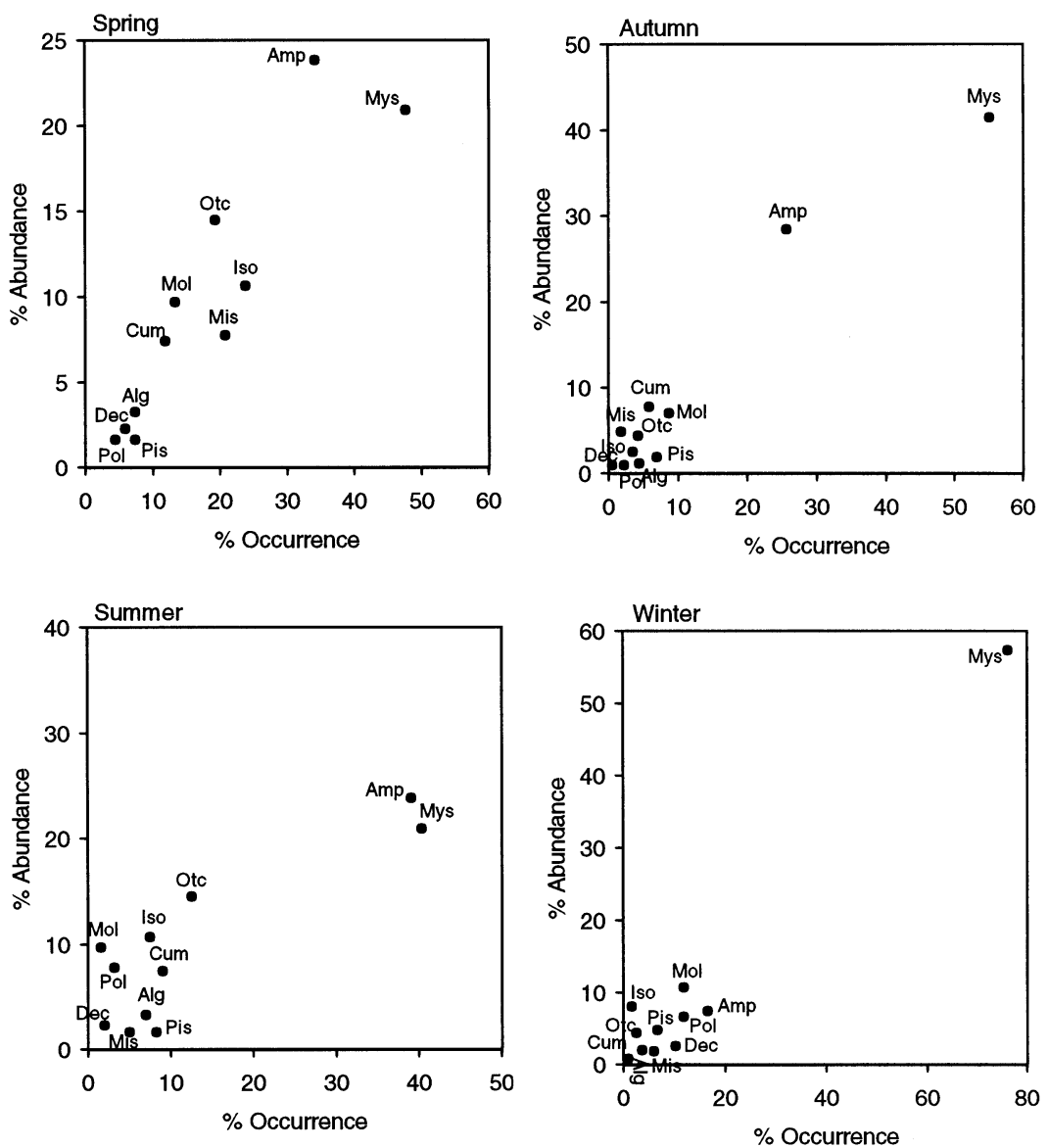

Fig. 3. Crangon crangon. Relative importance of major stomach contents for samples pooled by season: spring, summer, autumn and winter. See Fig. 2 for key to abbreviations sis for prey types, however, revealed significant differences despite elimination of most prey types in the order of prey types with high variation source (Table 6). This indicates that, except for a few food items (i.e. algae and miscellaneous categories), most of the prey types contribute to the variation between size classes.

There were significant interactions between the prey items, the size classes of shrimp and the seasons (Table 7). Significant interactions also occurred with partial associations (Table 7).

\section{Relation between predator size and prey size}

There were highly significant positive relationships between Crangon crangon size and prey size for mysids (Schistomysis spiritus) and amphipods (Gammarus sp.), but not for cumaceans (Iphinoë trispinosa) nor bivalves (Corbula sp.) (Table 8).

\section{Trophic diversity and equality}

Trophic diversity was generally low (Fig. 5A). For both size classes diversity was highest in spring, with little pattern during the rest of the year. No

Table 5. Crangon crangon. Contingency table analysis of the size class variation of 11 different categories of food items found in the stomachs. Values are total number of prey observed in each size, with expected values given in parentheses. $\chi^{2}-$ and $G-$ statistics are highly significant $\left({ }^{* *} \mathrm{p}<0.001\right)$

\begin{tabular}{|c|c|c|c|c|c|}
\hline Prey type & Small & Large & $N_{i}$ & $\chi^{2}$ & $G_{i}$ \\
\hline Polychaeta & $21(38)$ & $48(31)$ & 69 & 16.76 & 16.90 \\
\hline Mysidacea & $650(815)$ & $833(668)$ & 1483 & 74.17 & 73.69 \\
\hline Amphipoda & $609(476)$ & $257(390)$ & 866 & 82.61 & 85.84 \\
\hline Isopoda & $42(57)$ & $62(47)$ & 104 & 8.92 & 8.88 \\
\hline Cumacea & $135(76)$ & $4(63)$ & 139 & 99.83 & 131.74 \\
\hline Decapoda & 8 (29) & $44(23)$ & 52 & 32.89 & 35.11 \\
\hline Other crustaceans & $123(93)$ & $46(76)$ & 169 & 21.69 & 22.76 \\
\hline Mollusca & $132(113)$ & $74(93)$ & 206 & 6.92 & 7.05 \\
\hline Pisces & $15(44)$ & $65(36)$ & 80 & 42.36 & 44.43 \\
\hline Algae & $54(50)$ & $37(41)$ & 91 & 0.71 & 0.71 \\
\hline Miscellaneous & $46(44)$ & $34(36)$ & 80 & 0.21 & 0.21 \\
\hline $\mathrm{Ni}$ & 1835 & 1504 & 3339 & & \\
\hline$\chi^{2}$ & 174.35 & 212.73 & & $387.08^{* * *}$ & \\
\hline$G_{i}$ & 178.73 & 248.59 & & & $427.31^{* * *}$ \\
\hline
\end{tabular}


Table 6. Crangon crangon. Results of post hoc contingency table analysis (log-linear) of the seasonal variation of 11 different categories of food items found in the stomachs, after elimination of selected rows

\begin{tabular}{|c|c|c|c|}
\hline $\begin{array}{l}\text { Row(s) or column(s) } \\
\text { eliminated }\end{array}$ & $\begin{array}{l}\text { Significance } \\
\text { of } \chi^{2}\end{array}$ & $\begin{array}{l}\text { Sample } \\
\text { size }\end{array}$ & $\begin{array}{l}\text { Coefficient of } \\
\text { association }(\phi)\end{array}$ \\
\hline Cumacea & $\mathrm{p}<0.001$ & 3200 & 0.296 \\
\hline Cumacea, Amphipoda & $\mathrm{p}<0.001$ & 2334 & 0.245 \\
\hline Cumacea, Amphipoda, Mysidacea & $\mathrm{p}<0.001$ & 851 & 0.385 \\
\hline Cumacea, Amphipoda, Mysidacea, Pisces & $\mathrm{p}<0.001$ & 771 & 0.338 \\
\hline Cumacea, Amphipoda, Mysidacea, Pisces, Decapoda & $\mathrm{P}<0.001$ & 719 & 0.272 \\
\hline Cumacea, Amphipoda, Mysidacea, Pisces, Decapoda, other crustaceans & $\mathrm{p}<0.001$ & 550 & 0.245 \\
\hline Cumacea, Amphipoda, Mysidacea, Pisces, Decapoda, other crustaceans, polychaetes & $\mathrm{p}=0.001$ & 481 & 0.183 \\
\hline Cumacea, Amphipoda, Mysidacea, Pisces, Decapoda, other crustaceans, polychaetes & $\mathrm{p}=0.014$ & 275 & 0.176 \\
\hline
\end{tabular}

appreciable differences were observable between size classes in any season. Trends were similar for diet evenness (Fig. 5B).
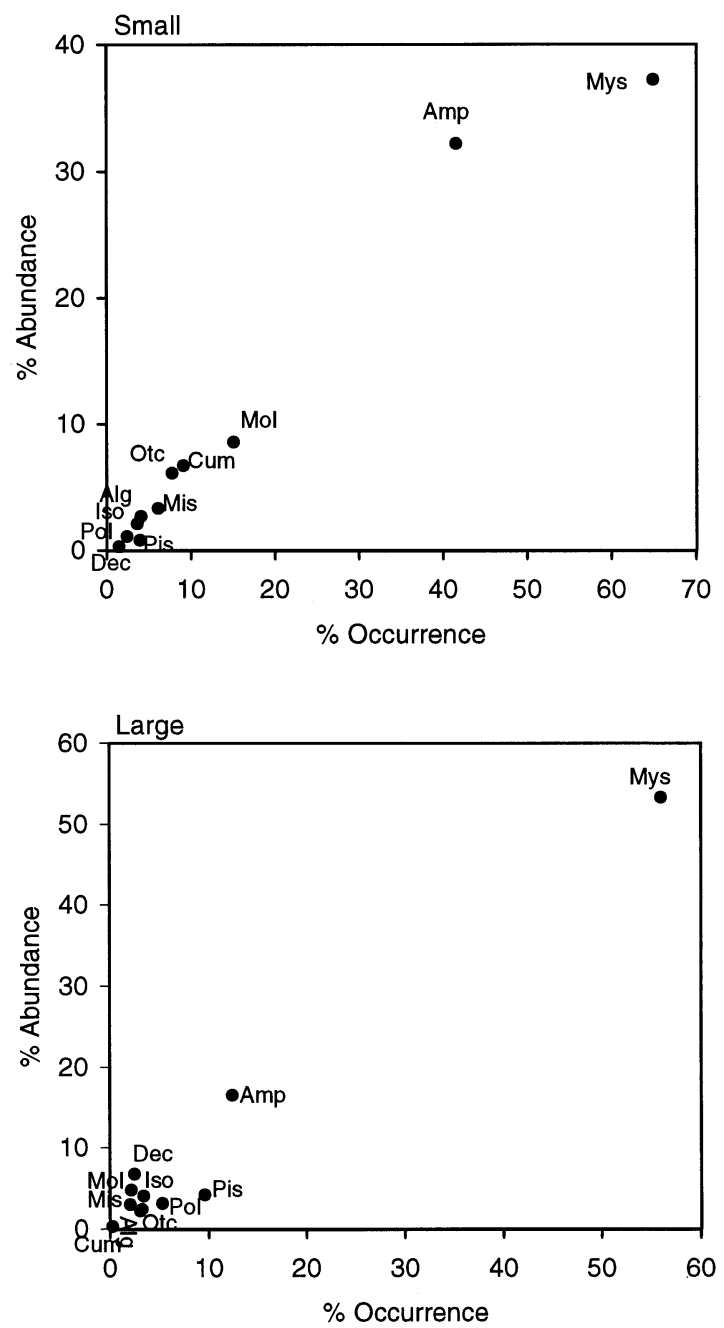

Fig. 4. Crangon crangon. Relative importance of major stomach content items for samples pooled by size classes: small $(<10 \mathrm{~mm} \mathrm{CL})$ and large size (>10 mm CL). See Fig. 2 for key to abbreviations
The higher index values in spring indicated that the prey items consumed were more evenly distributed, as demonstrated by the relative importance of seasonal diet composition. In other seasons, shrimp were more dependent on a few prey items with a lesser contribution from others.

\section{Dietary niche overlap}

Niche overlap $\left(R_{\mathrm{o}}\right)$ was higher among size classes within seasons than among seasons (Table 9). The Spearman rank coefficients were all significant. The maximum value occurred when the small and large

Table 7. Crangon crangon. Three-dimensional contingency table (log-linear) analysis testing for seasonal differences in the diet composition between 2 size-classes $[R$, row factor (11 prey types); $\mathrm{C}$, column factor (2 size-classes); $\mathrm{T}$, tier factor (4 seasons)]

\begin{tabular}{|c|c|c|c|}
\hline Factor & $\begin{array}{l}\text { Likelihood ratio } \\
\chi^{2} \text { statistic }\end{array}$ & df & $\mathrm{p}$ \\
\hline \multicolumn{4}{|c|}{ Mutual independence } \\
\hline $\mathrm{R} \times \mathrm{C} \times \mathrm{T}$ & 390.51 & 73 & $<0.001$ \\
\hline \multicolumn{4}{|c|}{ Partial independence } \\
\hline $\mathrm{R} \times(\mathrm{CT})$ & 322.64 & 70 & $<0.001$ \\
\hline $\mathrm{C} \times(\mathrm{RT})$ & 111.96 & 43 & $<0.001$ \\
\hline $\mathrm{T} \times(\mathrm{RC})$ & 276.85 & 63 & $<0.001$ \\
\hline
\end{tabular}

Table 8. Crangon crangon. Regression analysis between shrimp size $(x)$ and prey size $(y)$ for 4 prey items (ns, not significant)

\begin{tabular}{|lcccc|}
\hline Prey & $\mathrm{n}$ & Regressions & $\mathrm{r}^{2}$ & $\mathrm{p}$ \\
\hline Schistomysis spiritus & 37 & $y=1.104+0.185 x$ & $0.341<0.001$ \\
Gammarus sp. & 43 & $y=0.483+0.273 x$ & $0.398<0.001$ \\
Iphinoë trispinosa & 20 & $y=1.149+0.028 x$ & 0.031 & $\mathrm{~ns}$ \\
Corbula sp. & 29 & $y=1.350+0.019 x$ & 0.016 & $\mathrm{~ns}$ \\
& & & & \\
\hline
\end{tabular}



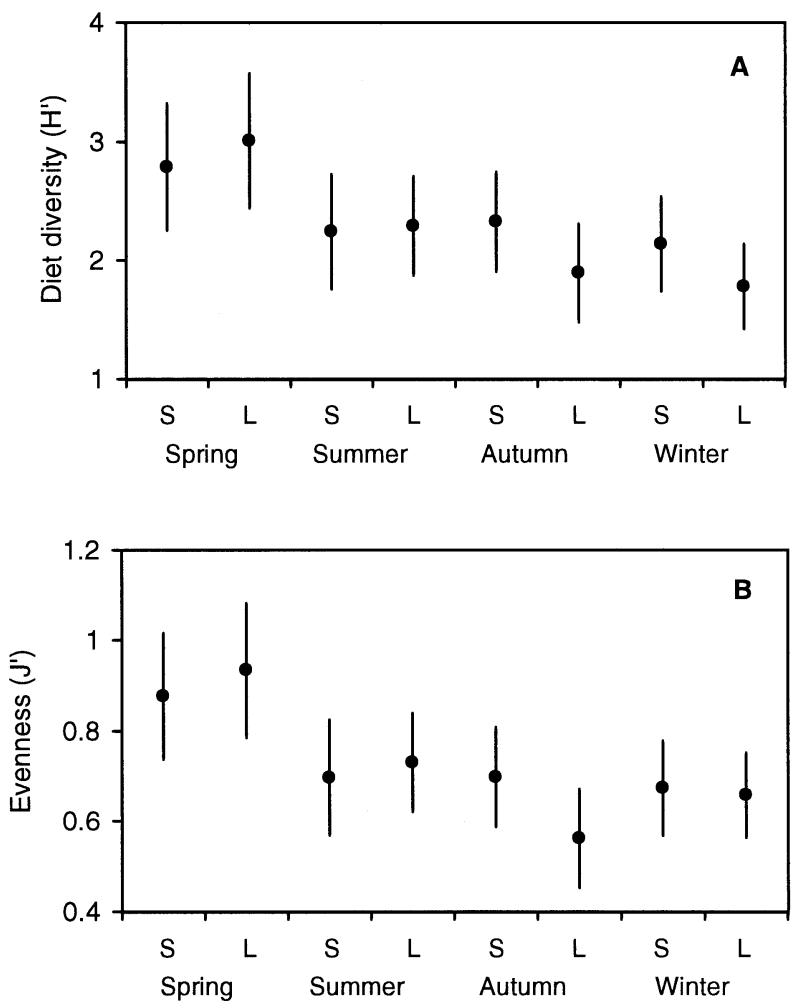

Fig. 5. Trophic diversity (A) and equality (B) of prey items found in small and large size classes of Crangon crangon at each season
Stomach fullness was lower in ovigerous females (Table 11, Fig. 6), which were a main source of variation, whilst patterns of fullness were similar between males and non-ovigerous females. When females with different ovarian condition were compared, stomach fullness declined from immature to mature individuals, indicating that feeding activity is affected by reproductive condition.

Over the moult cycle there was a significant 2-factor (fullness $\times$ moult stage) interaction (Table 11, Fig. 6). During premoult and postmoult less food was ingested than during intermoult. The percentage of shrimps with $<2.5$ points fullness was $36 \%$ in postmoult, $40 \%$ in premoult and $8 \%$ in intermoult. These results are confirmed by the largest $\chi^{2}$ values $\left(\chi^{2}=62.65\right)$ for 2.5 points among the levels of fullness (Table 11).

\section{Predation by shrimp on young fish}

A total of 74 fish remains (i.e. fish bodies and otoliths) were observed in 72 stomachs of Crangon crangon ranging from 7.2 to $15.8 \mathrm{~mm} \mathrm{CL}$ (Fig. 7). Occurrence was mainly in shrimp of 11 to $15 \mathrm{~mm} \mathrm{CL}$, with a peak in the 12 to $14 \mathrm{~mm}$ CL class. There was a significant difference between size classes in the level of occurrence (G-test: $\chi^{2}=20.47, \mathrm{df}=8, \mathrm{p}<0.01$ ). size classes were compared in summer, and, seasonally, in the summer to autumn comparison. All the $R_{\mathrm{o}}$ values indicate a considerable similarity in diet.

\section{Effects of season, sex, moult stage and ovarian condition on stomach fullness}

There were significant effects of season, sex, moult stage and ovarian condition on stomach fullness (Table 10). Shrimps with $<2.5$ points fullness were most frequent in spring and gradually decreased from summer through autumn to winter. In contrast, shrimps with $>75$ points increased from spring to winter (Fig. 6). The major sources of variation arose from those with $>75$ points, and, among seasons, from summer and spring (Table 11). There were important seasonal changes in feeding activity which were reflected in an increase in stomach fullness in autumn and winter.
Table 9. Crangon crangon. Niche overlap between the 2 size classes in each season, and between seasons, using Schoener overlap index $\left(R_{\mathrm{o}}\right)$ and Spearman rank correlation $\left(\mathrm{r}_{\mathrm{s}}\right.$ ) (in parentheses). ${ }^{*} \mathrm{p}<0.05,{ }^{* *} \mathrm{p}<0.01,{ }^{* * *} \mathrm{p}<0.001$

\begin{tabular}{|c|c|c|c|c|c|}
\hline & Size group & Spring & Summer & Autumn & Winter \\
\hline Spring & $\begin{array}{c}0.792 \\
\left(0.374^{*}\right)\end{array}$ & & $\begin{array}{c}0.593 \\
\left(0.537^{* *}\right)\end{array}$ & $\begin{array}{c}0.593 \\
\left(0.786^{* * *}\right)\end{array}$ & $\begin{array}{c}0.462 \\
\left(0.445^{* *}\right)\end{array}$ \\
\hline Summer & $\begin{array}{c}0.828 \\
\left(0.399^{*}\right)\end{array}$ & & & $\begin{array}{c}0.703 \\
\left(0.733^{* * *}\right)\end{array}$ & $\begin{array}{c}0.703 \\
\left(0.598^{* *}\right)\end{array}$ \\
\hline Autumn & $\begin{array}{c}0.668 \\
\left(0.658^{* * *}\right)\end{array}$ & & & & $\begin{array}{c}0.669 \\
\left(0.569^{* *}\right)\end{array}$ \\
\hline Winter & $\begin{array}{c}0.754 \\
\left(0.551^{*}\right)\end{array}$ & & & & \\
\hline
\end{tabular}

Table 10. Crangon crangon. Summary of (log-linear) contingency table analysis of season (4 levels), sex (3 levels), moult cycle (3 levels) and reproductive condition ( 3 levels) for 5 different categories of stomach fullness

\begin{tabular}{|lrrrcc|}
\hline Comparison & $\begin{array}{c}\text { Likelihood ratio } \\
\chi^{2} \text { statistic }\end{array}$ & & df & p & $\begin{array}{c}\text { Coefficient of } \\
\text { association }(\phi)\end{array}$ \\
\hline Fullness $\times$ season & 69.84 & 12 & $<0.001$ & 0.184 \\
Fullness $\times$ sex & 89.13 & 8 & $<0.001$ & 0.210 \\
Fullness $\times$ moult cycle & 146.77 & 8 & $<0.001$ & 0.140 \\
Fullness $\times$ reproductive condition & 22.05 & 8 & $<0.01$ & 0.278 \\
\hline
\end{tabular}



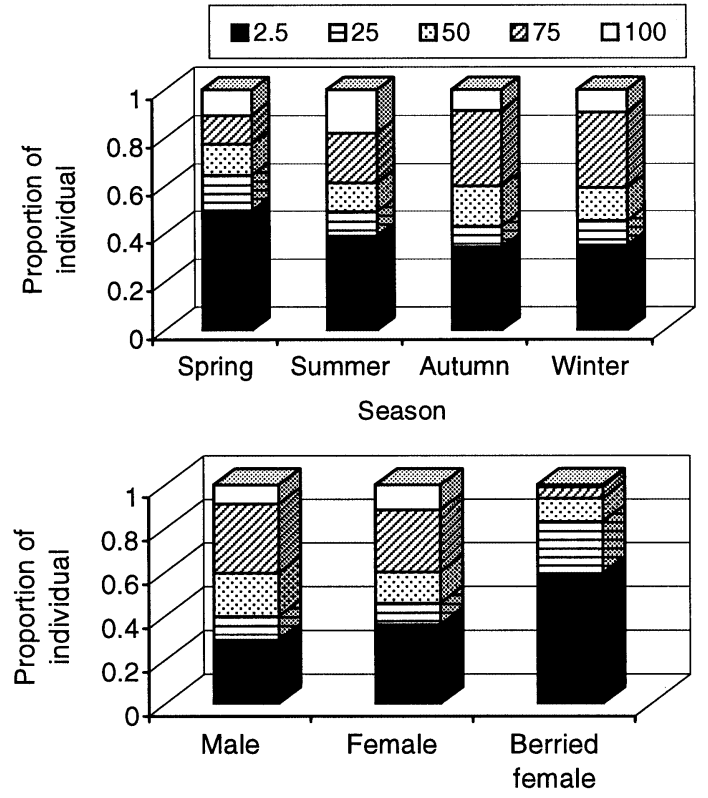

Sex
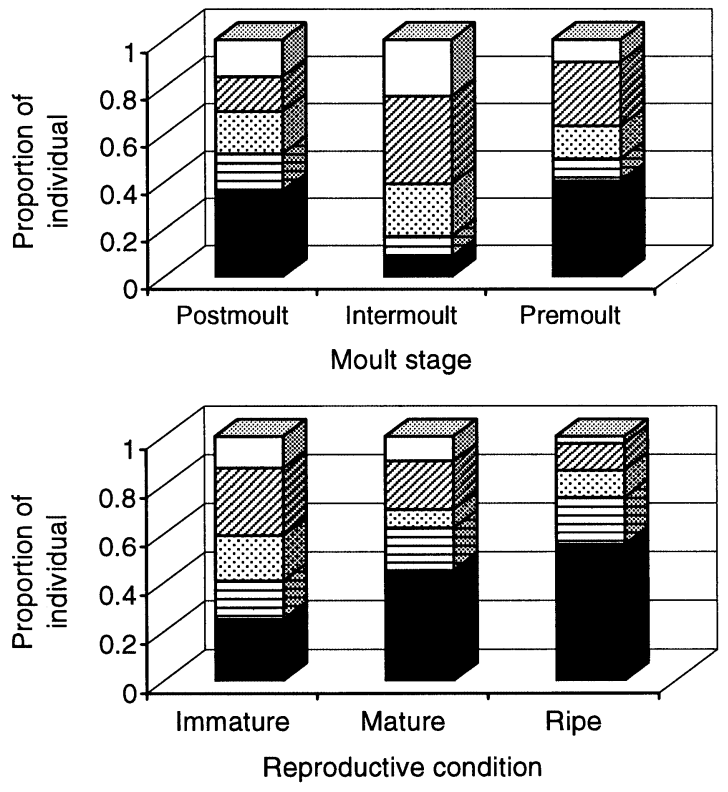

Fig. 6. Crangon crangon. Stomach fullness for different seasons, sexes, moult stages and reproductive conditions (ovarian maturation based only on female sample)

There were seasonal variations in the occurrence of fish remains in shrimp stomachs. Percentage occurrence was higher in autumn (39\%), summer (30\%) and spring $(26 \%)$ than in winter $(6 \%)$. Significant differences were found between seasons (G-test: $\chi^{2}=15.20$, $\mathrm{df}=3, \mathrm{p}<0.01$ ).

Female Crangon crangon showed greater preference for fish than did males. Females accounted for $86 \%$ of the total fish (mainly otoliths) found (76\% non-

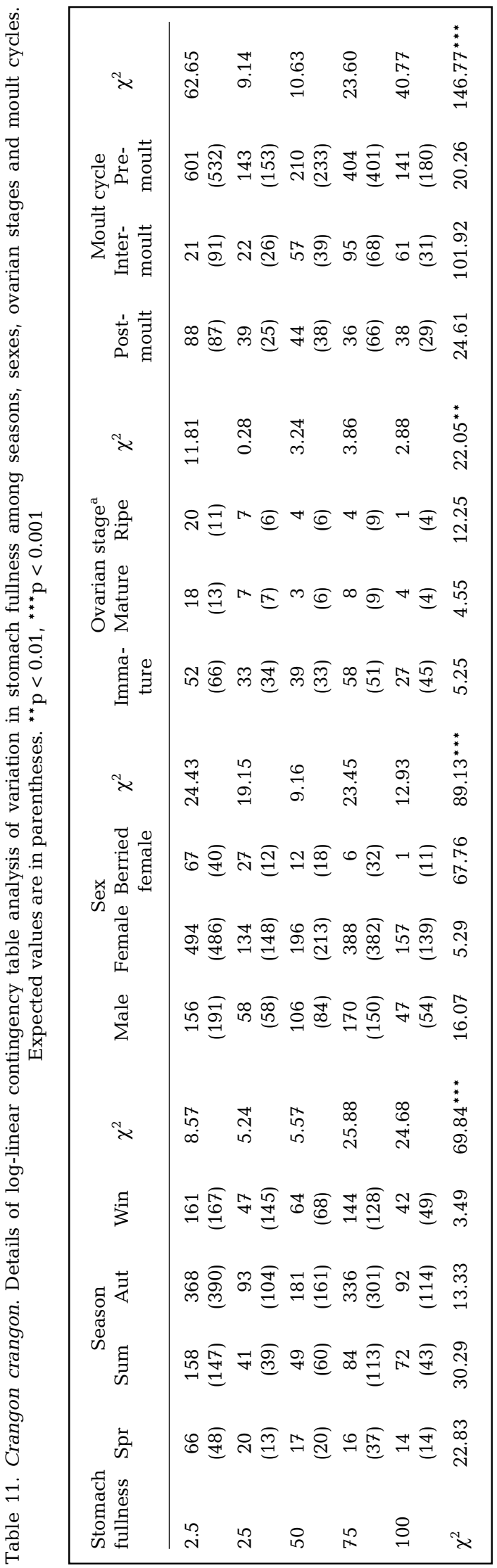




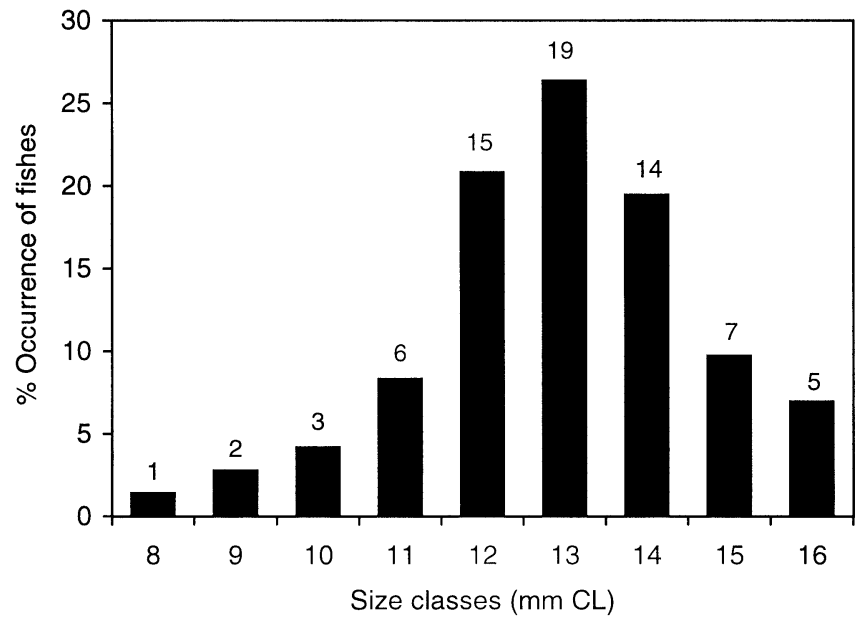

Fig. 7. Percentage occurrence of fishes by size class of Crangon crangon. Values above histogram blocks are observed numbers of fishes

ovigerous females and $10 \%$ ovigerous females), while males accounted for only $12 \%$. G-test revealed a significant difference in the occurrence of fish among males, non-ovigerous females and ovigerous females $\left(\chi^{2}=30.40\right.$, df $\left.=2, \mathrm{p}<0.001\right)$, indicating that nonovigerous females were mainly responsible for predation on fish.

\section{DISCUSSION}

The diet of Crangon crangon consisted of 3 predominantly bottom-dwelling categories: (1) demersal organisms (mysids, shrimps, fish, etc.); (2) epifaunal organisms (amphipods, isopods, gastropods, etc.); and (3) infaunal organisms (bivalves, cumaceans, foraminfera, nematoda, etc.). This diet, although including a diversity of prey, was dominated in all seasons by mysids and amphipods. Mysids, which are highly abundant in Port Erin Bay (Bruce et al. 1963), were invariably the most important prey category for all seasons and size groups. This carnivory on bottomdwelling organisms by C. crangon is typical of crangonid shrimps - see Crangon affinis De Haan (Kosaka 1970, Hong \& Oh 1989), C. allmani (Allen 1960), C. crangon (Lloyd \& Yonge 1947, Pihl \& Rosenberg 1984) and C. fraciscorum and C. nigricauda (Wahle 1985).

In the present study, mysids dominated the diet irrespective of season and size of shrimp, but this is not the case elsewhere: substrate types exert an influence. In areas with silt and clay, important components were meiofauna (ostracods, harpacticoids) and macrofauna (Mya arenaria, Cardium edule, Nereis spp., Corophium volutator) (Pihl \& Rosenberg 1984), whilst on sand, calanoid copepods dominated (Boddeke et al.
1986). Spatial and temporal availability of prey is considered the most important factor affecting the diet of both C. crangon (Tiews 1970, Pihl \& Rosenberg 1984) and other Crangon spp. (Wilcox \& Jeffries 1974, Wahle 1985).

In the current study mysids were the dominant food item for both small and large shrimps, but the smaller categories were more dependent on benthic prey, the larger ones on demersal organisms. A similar trend has been seen in other studies on Crangon crangon (Evans 1983, Pihl \& Rosenberg 1984, del Norte-Campos \& Temming 1994). Changes in diet with size have also been observed in other crangonids - Crangon fraciscorum and C. nigricauda in San Francisco Bay (Wahle 1985).

Various studies have shown that the size of invertebrate prey tends to increase with predator size (Menge \& Menge 1974, Birkeland 1974, Kohn \& Nybakken 1975, Levinton 1982), and this is generally true of crangonids - Crangon crangon (Tiews 1970, Pihl \& Rosenberg 1984) and C. franciscorum and C. nigricauda (Wahle 1985). In our study, predation by C. crangon on mysids (Schistomysis spiritus) and amphipods (Gammarus sp.) was significantly size dependent, but predation on cumaceans (Iphinoë trispinosa) and bivalves (Corbula sp.) was not. This suggests that prey size selectivity is effective for demersal and epifaunal prey, but not for infauna. A similar divergence in strategy was found in the blue crab Callinectes sapidus (Blundon \& Kennedy 1982a,b, West \& Williams 1986, Stoner \& Buchanan 1990, Hsueh et al. 1992). Distinct preferences were shown for particular size classes of some visually hunted nektonic and epifaunal prey, presumably because of the smaller energy investment needed for capture. However, there was little size selection for infauna, the excavation of which requires greater energy. Nevertheless, in the Dutch Wadden Sea and on the Swedish coast, several studies have shown that predation by C. crangon on infauna such as Macoma, Cerastoderma and Mya can be size selective (Pihl \& Roseneberg 1984, Jensen \& Jensen 1985, Keus 1986, Beukema et al. 1998, van der Veer et al. 1998). In these highly productive sediments (Möller et al. 1985) bivalve spat is very dense, which may make size selection cost effective.

Trophic diversity indices varied little among size classes, but were higher in spring than in other seasons, a likely consequence of a seasonal increase in diversity of prey items. In all seasons a high food niche overlap indicated intraspecific competition between size groups - a result also found in the laboratory (Nilsson et al. 1993). Interspecific competition is also indicated. A comparison between the diet of Crangon crangon and the 5 dominant fish in the same area over the same periods (S. de la Rosa, unpubl. data, Port Erin 
Table 12. Dietary overlap index $\left(R_{\mathrm{o}}\right)$ between Crangon crangon $(\mathrm{Cc})$ and 5 dominant species in Port Erin Bay, using unpublished data $(\mathrm{Pl}$, Pleuronectes platessa; $\mathrm{Mm}$, Merlangius merlangus; Gm, Gadus morhua; $\mathrm{Pv}$, Pollachius virens; $\mathrm{Pp}$, Pollachius pollachius)

\begin{tabular}{|lccccc|}
\hline Species & $\mathrm{Pl}$ & $\mathrm{Mm}$ & $\mathrm{Gm}$ & $\mathrm{Pv}$ & $\mathrm{Pp}$ \\
\hline $\mathrm{CC}$ & 0.759 & 0.592 & 0.564 & 0.471 & 0.402 \\
\hline
\end{tabular}

Marine Laboratory) (Table 12) showed the largest food niche overlap between $C$. crangon and plaice Pleuronectes platessa. On the Swedish coast, Evans (1983) and Pihl (1985) also found a large niche overlap between these 2 species.

Stomach fullness was affected by both extrinsic (season) and intrinsic (sex, ovarian development, moult cycle) factors, and was relatively low in spring and summer, the main reproductive period (Lloyd \& Yonge 1947, Meredith 1952, Henderson \& Holmes 1987). Females carrying eggs or with advanced ovarian development show reduced feeding activity (Plagman 1939, Lloyd \& Yonge 1947) for 2 reasons: (1) ovigerous decapods cannot moult until the eggs hatch (Hartnoll 1982, 1985), which reduces the stimulus for feeding; and (2) the large size of the ripening ovaries (Meredith 1952, Haefner \& Spaargaren 1993, Spaargaren \& Haefner 1998) constrains the space for stomach expansion. Lower values of stomach fullness occur in the postmoult and premoult stages. This has been observed in other shrimps (Wassenberg \& Hill 1984, Harpaz et al. 1987), lobsters (Chittleborough 1975) and crabs (Hill 1976, Williams 1982, Abelló \& Cartes 1987, O'Halloran \& O'Dor 1988, Norman \& Jones 1992, Freire \& González-Gurriarán 1995, Freire 1996). The difference tends to be less clearcut in carideans, because the intermoult stage is generally much shorter relative to the duration of the moult cycle, than in brachyurans (Passano 1960, Scheer 1960). The premoult stage (D) in carideans generally comprises over two-thirds of the moult cycle (Scheer 1960, Smith \& Dall 1985).

Between spring and autumn, fish remains were common in the stomachs of larger shrimps. Otolith identification shows that the prey were 0 -group specimens of plaice Pleuronectes platessa, dab Limanda limanda and sand eel Ammodytes tobianus (A. J. Geffen, pers. comm., Port Erin Marine Laboratory), suggesting that predation by Crangon crangon may be 1 of the factors in the study area affecting survival of newly settled 0group fish. This has been shown for plaice in the North Sea (Arndt \& Nehls 1964, van der Veer 1986, van der Veer \& Bergman 1987, Cushing 1996) and on the west coast of Scotland (Ansell et al. 1999). Thus, van der Veer \& Bergman (1987) demonstrated by enclosure experiments that shrimps were the predators responsible for density-dependent mortality of plaice. Similar observations have been published for the sevenspine bay shrimp Crangon septemspinosa preying on the flounder Pleuronectes americanus (Bertram \& Leggett 1994, Witting \& Able 1995). However, the interactions between the shrimps and co-occurring fish are in fact much more complicated, because shrimps and fish function as both prey and predators for each other at different stages of their life histories.

Acknowledgements. Shrimp were obtained from a programme examining the dynamics of sandy bays, NERC Grant GST/02/902 to R.D.M.N. During this work, C.W.O was partially supported by a postgraduate studentship from the Foundation for the Rural Youth, South Korea.

\section{LITERATURE CITED}

Abelló P, Cartes J (1987) Observaciones sobre la alimentación Liocarcinus depurator (L.) (Brachyura: Portunidae) en el Mar Catalán. Invest Pesq 51(Suppl 1):413-419

Allen JA (1960) On the biology of Crangon allmani Kinahan in Northumberland waters. J Mar Biol Assoc UK 39: 481-508

Allen JA (1966) The dynamics and interrelations of mixed population of Caridea found off the north-east coast of England. In: Barnes H (eds) Some contemporary studies in marine science. George Allen \& Unwin, London, p 45-66

Ansell AD, Comely CA, Robb L (1999) Distribution, movements and diets of macrocrustaceans on a Scottish sandy beach with particular reference to predation on juvenile fishes. Mar Ecol Prog Ser 176:115-130

Arndt EA, Nehls HW (1964) Nahrungsuntersuchungen an Postlarvalstadien und Jungtieren von Pleuronectes flesus L. Pleuronectes platessa L. in der äußeren Wismarer Bucht. Z Fisch 12:45-73

Bertram DF, Leggett WC (1994) Predation risk during the early life history periods of fishes: separating the effects of size and age. Mar Ecol Prog Ser 109:105-114

Beukema JJ (1992) Dynamics of juvenile shrimp Crangon crangon in a tidal-flat nursery of the Wadden Sea after mild and cold winters. Mar Ecol Prog Ser 83:157-165

Beukema JJ, Honkoop PJC, Dekker R (1998) Recruitment in Macoma balthica after mild and cold winters and its possible control by egg production and shrimp predation. Hydrobiologia 376:23-34

Birkeland C (1974) Interaction between a sea pen and seven of its predators. Ecol Monogr 44:211-232

Blundon JA, Kennedy VS (1982a) Mechanical and behavioral aspects of blue crab (Callinectes sapidus Rathbun) predation on Chesapeake Bay bivalves. J Exp Mar Biol Ecol 65: 47-65

Blundon JA, Kennedy VS (1982b) Refuges for infaunal bivalves from blue crab Callinectes sapidus (Rathbun) predation in Chesapeake Bay. J Exp Mar Biol Ecol 65: $67-81$

Boddeke R, Drissen G, Doesburg W, Ramaekers G (1986) Food availability and predator presence in a coastal nursery area of the brown shrimp (Crangon crangon). Ophelia 26:77-90

Bonsdorff E, Pearson TH (1997) The relative impact of physical disturbance and predation by Crangon crangon on 
population density in Capitella capitella: an experimental study. Opelia 46:1-10

Bruce JR, Colman JS, Jones NS (1963) Marine fauna of the Isle of Man. Liverpool University Press, Liverpool

Cartes JE, Sardà F (1989) Feeding ecology of the deep-water aristeid crustacean Aristeus antennatus. Mar Ecol Prog Ser 54:229-238

Chittleborough RG (1975) Environmental factors affecting growth and survival of juvenile western rock lobster Panulius longipes (Milne-Edwards). Aust J Mar Freshw Res 26:177-196

Cody ML, Diamond JM (1975) Ecology and evolution of communities. The Belknap Harvard University Press, Cambridge

Cortés E (1997) A critical review of methods of studying fish feeding based on analysis of stomach contents: application to elasmobranch fishes. Can J Fish Aquat Sci 54: 726-738

Crow ME (1982) Some statistical techniques for analyzing the stomach contents of fish. In: Lipovsky SJ, Simenstad CA (eds) Fish food habits studies: proceedings of the 3rd Pacific northwest technical workshop. University of Washington, Seattle, Washington, p 8-15

Cushing DH (1996) Towards a science of recruitment in fish populations. Ecology Institute, Oldendorf/Luhe, Germany

del Norte-Campos AGC, Temming A (1994) Daily activity, feeding and rations in gobies and brown shrimp in the northern Wadden Sea. Mar Ecol Prog Ser 115:41-50

Evans S (1983) Production, predation and food niche segregation in a marine soft bottom community. Mar Ecol Prog Ser 10:147-157

Evans S (1984) Energy budgets and predation impact of dominant epibenthic carnivores on a shallow soft bottom community at the Swedish west coast. Estuar Coast Shelf Sci 18:651-672

Evans S, Tallmark B (1985) Niche separation within the mobile predator guild on marine shallow soft bottoms. Mar Ecol Prog Ser 23:279-286

Freire J (1996) Feeding ecology of Liocarcinus depurator (Decapoda: Portunidae) in the Ría de Arousa (Galicia, north-west Spain): effects of habitats, season and life history. Mar Biol 126:297-311

Freire J, González-Gurriarán E (1995) Feeding ecology of the velvet swimming crab Necora puber in mussel raft areas of the Ría de Arousa (Galicia, NW Spain). Mar Ecol Prog Ser 119:139-154

Haefner PA Jr, Spaargaren DH (1993) Interactions of ovary and hepatopancreas during the reproductive cycle of Crangon crangon (L.). 1. Weight and volume relationships. J Crustac Biol 13:523-531

Harpaz S, Kahan D, Galun R (1987) Variability in feeding behavior of the Malaysian prawn Macrobrachium rosenbergii (De Man) during the moult cycle (Decapoda, Caridea). Crustaceana 52:53-60

Hartnoll RG (1982) Growth. In: Abele LG (eds) The biology of Crustacea. Vol. 2. Embryology, morphology and genetics. Academic Press, New York, p 111-196

Hartnoll RG (1985) Growth, sexual maturity and reproductive output. In: Wenner AM (eds) Custacean Issues 3: factors in adult growth. AA Balkema, Rotterdam, p 101-128

Hedqvist-Johnson K, Andre C (1991) The impact of the brown shrimp Crangon crangon L. on soft-bottom meiofauna: an experimental approach. Ophelia 34:41-49

Henderson PA, Holmes RHA (1987) On the population biology of the common shrimp Crangon crangon (L.) (Crustacea: Caridea) in the Severn Estuary and Bristol Channel. J Mar Biol Assoc UK 67:825-847
Hill BJ (1976) Natural food, foregut clearance-rate and activity of the crab Scylla serrata. Mar Biol 34:109-116

Hong SY, Oh CW (1989) Ecology of the sand shrimp, Crangon affinis, in the Nakdong River estuary, Korea. Bull Korean Fish Soc 22:351-362

Hsueh PW, McClintock JB, Hopkins TS (1992) Comparative study of the diets of the blue crabs Callinectes similis and C. sapidus from a mud bottom habitat in Mobile Bay, Alabama. J Crustac Biol 12:615-619

Hynes HBN (1950) The food of fresh-water sticklebacks (Gasterosteus aculeatus and Pygosteus pungitus), with a review of methods used in studies of the food of fishes. J Anim Ecol 19:36-58

Hyslop EJ (1980) Stomach contents analysis - a review of methods and their application. J Fish Biol 17:411-429

Jensen KT, Jensen JN (1985) The importance of some epibenthic predators on the density of juvenile benthic macrofauna in the Danish Wadden Sea. J Exp Mar Biol Ecol 89:157-174

Jonsson BK, Sundbäck K, Nisson P, Nilsson C, Swanberg IL, Ekebom J (1993) Does the influence of the epibenthic predator Crangon crangon L. (brown shrimp) extend to sediment microalgae and bacteria. Neth J Sea Res 31:83-94

Keus B (1986) De predatie van de garnnal (Crangon crangon) op het broed van het nonnetie (Macoma balthica). Interne Verslagen Nederlands Instituut voor Ondserzoek der Zee, Texel

Kohn AJ, Nybakken JW (1975) Ecology of Conus on eastern Indian Ocean fringing reefs: diversity of species and resource utilization. Mar Biol 29:211-234

Kosaka M (1970) On the ecology of the sand shrimp, Crangon affinis De Haan, as a prey of the demersal fishes in Sendai Bay. J Coll Mar Sci Technol Tokai Univ 4:59-80

Kuipers BR, Dapper R (1981) Production of Crangon crangon in the tidal zone of the Dutch Wadden Sea. Neth J Sea Res 15:33-53

Levinton JS (1982) Marine ecology. Prentice-Hall, Englewood Cliffs, NJ

Lloyd A, Yonge CM (1947) The biology of Crangon crangon L. in the Bristol Channel and Severn Estuary. J Mar Biol Assoc UK 26:626-661

Menge JL, Menge BA (1974) Role of resource allocation, aggregation and spatial heterogeneity in coexistence of two competing starfish. Ecol Monogr 44:189-209

Meredith SS (1952) A study of Crangon vulgaris in the Liverpool Bay area. Proc Trans Liverpool Biol Soc 58:75-109

Möller P, Pihl L, Rosenberg R (1985) Benthic faunal energy flow and biological interaction in some shallow marine soft bottom habitats. Mar Ecol Prog Ser 27:109-121

Nash RDM, Geffen AJ, Hughes G (1992) Winter growth of juvenile plaice on the Port Erin Bay (Isle of Man) nursery ground. J Fish Biol 41:209-215

Nash RDM, Geffen AJ, Hughes G (1994) Individual growth of juvenile plaice (Pleuronectes platessa L.) on a small Irish sea nursery ground (Port Erin Bay, Isle of Man, UK). Neth J Sea Res 32:369-378

Nilsson P, Sundbäck K, Jonsson B (1993) Effect of the brown shrimp Crangon crangon L. on endobenthic macrofauna, meiofauna and meiofaunal grazing rates. Neth J Sea Res 31:95-106

Norman CP, Jones MB (1992) Influence of depth, season and moult stage on the diet of the velvet swimming crab NeCora puber (Brachyura, Portunidae). Estuar Coast Shelf Sci 34:71-83

Oh CW, Hartnoll RG, Nash RDM (1999) Population dynamics of the common shrimp, Crangon crangon (L.), in Port Erin Bay, Isle of Man, Irish Sea. ICES J Mar Sci 56:718-733 
O'Halloran MJ, O'Dor RK (1988) Molt cycle of male snow crabs, Chionoecetes opilio, from observations of external features, setal changes, and feeding behavior. J Crustac Biol 8:164-176

Passano LM (1960) Molting and its control. In: Waterman TH (eds) The physiology of Crustacea. Vol. I. Metabolism and growth. Academic Press, New York, p 473-536

Paul RKG (1981) Natural diet, feeding and predatory activity of the crabs Callinectes arcuatus and $C$. toxotes (Decapoda, Brachyura, Portunidae). Mar Ecol Prog Ser 6: 91-99

Pielou EC (1975) Ecological diversity. Wiley, New York

Pihl L (1985) Food selection and consumption of mobile epibenthic fauna in shallow marine areas. Mar Ecol Prog Ser 22:169-179

Pihl L, Rosenberg R (1984) Food selection and consumption of the shrimp Crangon crangon in some shallow marine areas in western Sweden. Mar Ecol Prog Ser 15: 159-168

Pirrie ME, Bruce JR, Moore HB (1932) A quantitative study of the fauna of sandy beach at Port Erin. J Mar Biol Assoc UK $18: 279-296$

Plagmann J (1939) Ernährungsbiologie der Garnele (Crangon vulgaris Fabr.). Helgol Wiss Meeresunters 2:113-162

Price KS (1962) Biology of the sand shrimp, Crangon septemspinosa, in the shore zone of the Delaware Bay Region. Chesapeake Sci 3:244-255

Redant F (1984) An indexed bibliography on the common shrimp, Crangon crangon (L.), complementary to Tiews, 1967. Int Counc Explor Sea Comm Meet (Shellfish Comm) $\mathrm{K}: 2: 1-34$

Reise K (1978) Experiments on epibenthic predation in the Wadden Sea. Helgol Wiss Meeresunters 31:55-101

Reise K (1985) Tidal flat ecology. An experimental approach to species interactions. Springer-Verlag, Berlin

Scheer BT (1960) Aspects of the intermolt cycle in natantians. Comp Biochem Physiol 1:3-18

Schoener TW (1970) Nonsynchronous spatial overlap of lizards in patchy habitats. Ecology 51:408-418

Schumacher A, Tiews K (1979) On the population dynamics of the brown shrimp (Crangon crangon L.) off the German coast. Rapp P-V Reun Cons Int Explor Mer 175:280-286

Smith DM, Dall W (1985) Moult staging the tiger prawn Penaeus esculentus. In: Rothlisberg PC, Hill BJ, Staples DJ (eds) Second Australian national prawn seminar. NPS2, Cleveland, Australia, p 85-93

Editorial responsibility: Otto Kinne (Editor),

Oldendorf/Luhe, Germany
Sokal RR, Rohlf FJ (1995) Biometry. WH Freeman \& Co, New York

Spaargaren DH, Haefner PA Jr (1998) Quantitative changes during ovarian development in the brown shrimp Crangon crangon (L., 1758) (Decapoda, Natantia). Crustaceana 71:247-257

Tiews K (1970) Synopsis of biological data on the common shrimp, Crangon crangon (Linnaeus, 1758). FAO Fish Rep 4:1167-1224

van der Veer HW (1986) Immigration, settlement and density dependent mortality of larval and postlarval 0 group plaice (Pleuronectes platessa) population in the Wadden Sea. Mar Ecol Prog Ser 29:223-236

van der Veer HW, Bergman JN (1987) Predation by crustaceans on a newly settled 0-group plaice Pleuronectes platessa population in the western Wadden Sea. Mar Ecol Prog Ser 35:203-215

van der Veer HW, Feller RJ, Weber A, Witte JIJ (1998) Importance of predation by crustaceans upon bivalve spat in the intertidal zone of the Dutch Wadden Sea as revealed by immunological assays of gut contents. J Exp Mar Biol Ecol 231:139-157

Wahle RA (1985) The feeding ecology of Crangon franciscorum and Crangon nigricauda in San Francisco Bay, California. J Crustac Biol 5:311-326

Wassenberg TJ, Hill BJ (1984) Moulting behaviour of the tiger prawn Penaeus esculentus (Haswell). Aust J Mar Freshw Res 35:561-571

Wear RG, Haddon M (1987) Natural diet of the crab Ovalipes catharus (Crustacea, Portunidae) around central and northern New Zealand. Mar Ecol Prog Ser 35:39-49

West DL, Williams AH (1986) Predation by Callinectes sapidus (Rathbun) within Spartina alterniflora (Loisel) marches. J Exp Mar Biol Ecol 100:75-95

Wilcox JR, Jeffries HP (1974) Feeding habitats of the sand shrimp, Crangon septemspinosa. Biol Bull 146:424-434

Williams ML (1982) Natural food and feeding in the commercial sand crab Portunus pelagicus Linnaeus, 1766 (Crustacea: Decapoda: Portunidae). J Exp Mar Biol Ecol 59: 165-176

Witting DA, Able KW (1995) Predation by Sevenspine Bay shrimp Crangon septemspinosa in winter flounder Pleuronectes americanus during settlement laboratory observations. Mar Ecol Prog Ser 123:23-31

Zar JH (1984) Biostatistical analysis. Prentice Hall, Engelwood Cliffs, NJ

Submitted: September 2, 1999; Accepted: November 9, 2000 Proofs received from author(s): April 4, 2001 